\title{
Quality Analysis of Vilnius City Suburban Spatial Development
}

\author{
Dovilè Lazauskaitè, Aušrinè Griškevičiūtè-Gečienè, Edita Šarkienė, Virginija Zinkevičienė \\ Vilnius Gediminas Technical University, Department of Urban Engineering, Sauletekio ave. 11, 10223 Vilnius, Lithuania
}

\begin{abstract}
Qualifying European regional policy and treating structural functional remote urban parts as a functional urban region, attention is drawn to the increasing regional integration and the necessity to reduce the barriers for even development between cities and its surrounding rural areas is emphasized. Tendency of city and district municipalities to take positions of independent actors and a big benevolence for a private initiative has created opportunities over 20 years of independent Lithuania for everyone to shape their own living space.

Urban development occurs in newly emerging suburban areas and continues to spread to rural areas. Result of this process - the emptying central parts of the cities. Application of sustainable urban planning theory in Lithuanian spatial planning practice has gained official status, but that status often ends where the planned city limits end. Meanwhile, the needs of the population show increase of the city limits borders permeability. The objective of the quality analysis of Vilnius city suburban areas development is associated with most intensively growing Vilnius district settlements, falling in to dominant influence of Vilnius city area. The authors examine the lack of integrity in urban and rural systems.

The analysis includes identification of the real problems in urbanized areas and quality assessment of objective / subjective systematic connections, considering not usual political, historical, functional and morphological criteria, but in accordance to the fundamental principles of sustainability identification. Trying to assess urban and rural areas integration in practice, four fastest growing rural settlements in the district of Vilnius has been selected, located at the main roads leading into the city (Avižieniai, Skaidiškejs, Pagiriai, Didžioji Riešè). Considering selected parameters characterising consistency, there has been connections between rural and urban areas identified, its numerical values calculated, and using multipurpose decisions support system, assessment findings are presented. The conclusions present evaluation of the impact of the identified connections to the urban system.
\end{abstract}

Keywords: Suburban areas; living environment quality; assessment indicators.

\section{Introduction}

Suburban zone is most seriously exposed to urban sprawl, a phenomenon which is commonly observed across the world, Europe not excluded [1]. It can also be noticed in new EU's member states (acceded to the Union in 2004, and later), until recently socialist countries [2], as well as areas undergoing a demographic downturn [3]. The centralized planning and the non-existence of land markets resulted in more compact cities compared to the western counterpart. In the cities of Central and Eastern countries have been founded some commonalities: general decline in population, privatization of the housing stock, gradual deterioration of housing blocs, progressive deterioration of city centres, increasing the opportunities in the service sector, commercial development, raised the prices in the inner city, increase of pollution [4]. Therefore, suburbanization is considered to be a natural urban development stage of the post Soviet countries living through active changes.

Negative consequences of the extensive expansion are most likely to appear around major urban centres, because intensity of the suburban development processes and size of the impact zone depends on central city generating expansion and the properties of its geographical situation: economic potential, configuration of the administrative area, development of the communication system and others.

Rural areas around the biggest Lithuanian cities where occupied with valueless "suburban landscape", without urban infrastructure, public spaces and with degradated relief, forests, hydrological systems and etc. Analysis of the current development of suburban areas of the biggest Lithuanian cities shows, that development takes place regardless of emerged settlements network in suburban areas and slow development of communications and engineering infrastructure. Master plan of Vilnius city and rural municipalities of Vilnius plans do not indicate the demographical reality and are under the permanent changes process [5]. Research data of Vilnius district general plan shows, that the sintering pressure of Vilnius

Corresponding author: Dovilè Lazauskaitè. E-mail address: dovile.lazauskaite@vgtu.lt

http://dx.doi.org/10.3846/enviro.2014.126

(C) 2014 The Authors. Published by VGTU Press. This is an open-access article distributed under the terms of the Creative Commons Attribution License, which permits unrestricted use, distribution, and reproduction in any medium, provided the original author and source are credited. 
city for the Vilnius district elderships bordering with the city is high and will remain so in the future, whereas the continuous quality decrease of the living environment of Vilnius city, rush of the residents of Vilnius city to Vilnius district will remain significant. In addition, municipality of Vilnius district has one of the lowest economic score of land in the country not encouraging engaging in agriculture. (The process mainly takes place spontaneously, where there is necessity of changes in legal framework, material and intellectual recourses and skills in order to control it).

Intention to use the land for construction in comparison with the agricultural use leads just to "draw the settlements" and gratify expectations of municipality heads and citizens to have much territories as they want for their land investment [5]. Vilnius city planners emphasized this process as the main reason why Vilnius city has been surrounded by chaotic urban structures and poor landscapes.

Chaotic construction development outside the city is also associated with other issues, which are being solved slowly due to the prevailing legislative or legal constraints regulating the process.

This paper is focused on changes in peripheral urban areas taking the urban population development on board in the analyses even urban areas and their relations to differing types of peripheral areas. Rural areas have different migration patterns where neighbour rural areas in the surrounding of big cities have experienced a positive population development as an effect of both natural population increase and net in-migration. The first part after introductory chapter is primarily concentrated on the role of population in the peripheral areas development process and how its impact has changed over time and the factors behind this transformation process. This is based on reviews of scientific literature and empirical analysis. Many rural areas have outperformed urban areas and been transformed in a more urban way with regard to their structure. The rural areas in the neighbourhood to big cities have experienced the structural transformation and in migration of people with an urban life-style both in private and economic sense. In order to investigate the differing development quality paths and preconditions for transformation in Vilnius peripheral territories are used the living quality assessment of urban-rural dimensions. The paper contains also a description of different kind of demographic, socio-economic, environmental and political processes performed the sustainable development in peripheral areas and subjective and objective indicators that shall be used for the assessment of living environment in these areas. The paper ends up with a discussion of future perspectives for qualitative development of city peripheral rural areas.

\subsection{Suburban areas and their location in regard to the city}

From the perspective of regional and national settlement systems, the suburban zone forms a part of the urban agglomeration, which also comprises the city's central and external districts [1]. However, the suburbs created by uncontrolled development are mostly amorphous, do not have strict and formal boundaries, therefore it is quite complicated to define the exact boundaries of the zone. Concentration of the population (number) is perhaps the most import indicator that can reveal the boundaries of the major cities development. Large cities with 250 thousands and more of the population, creates around itself suburban zone continuing outside administrational limits till 20-30 kilometres [6]. In addition, the city's periphery of the beginning is based on the public transport infrastructure development. For example, the peripheral part of the city of Vilnius beginning expressed to stable and fair service zone by public transport ending and the beginning of car dominance [7].

Peripheral zone in Vilnius city master plan designated as part of the city, outside the city municipal area. Peripheral zone, in one of the most important spatial planning documents dedicated for the country's capital, displayed based on theoretical city zoning did not reflect a more detailed layout description of suburban areas in relation to the city, see Figure 1.

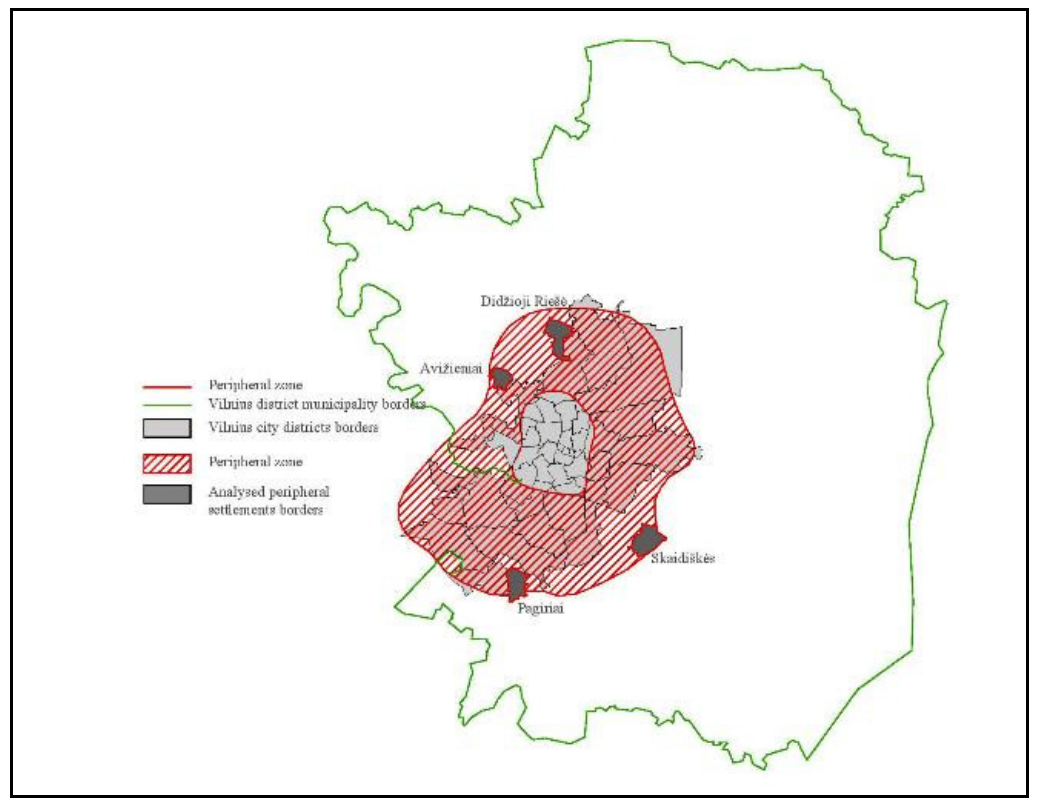

Fig. 1. Peripheral zones of Vilnius city 
Layout of peripheral zone in respect to city centre, further development trends are important and significant factor in the actual structure of the city and the district.

Peripheral urban zone based on theoretical city zoning model, in practical terms is surrounded by a lot of uncertainty in the wider area, influenced by subjective government, business and population interests [8].

This paper analyses the four villages in the district of Vilnius, located in the area of Vilnius district municipality and according to Vilnius city major plan falling to peripheral zone of the country's capital, see Figure 2.

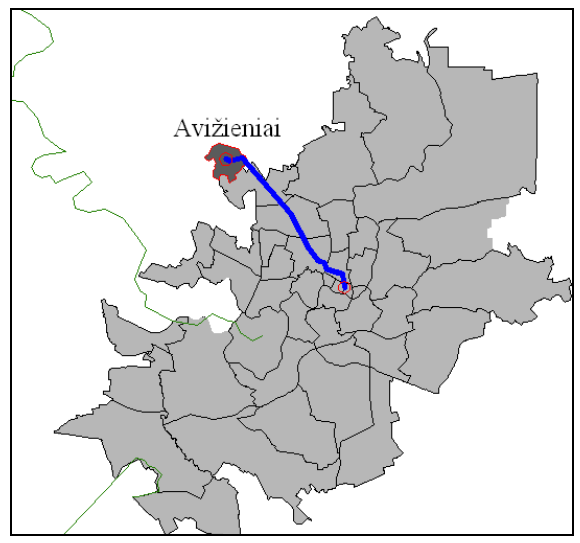

(a)

The village (population 2125 )* from Vilnius city centre is located about $13 \mathrm{~km}$ north-west direction and is located $1 \mathrm{~km}$ head into the west from public highway A2 (Vilnius-Panevezys). Avižieniai eldership's centre. Former Soviet economic gardening central settlement

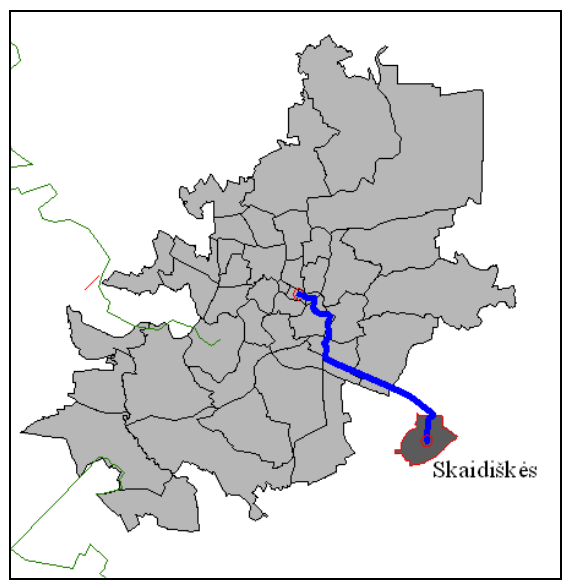

(c)

The village (population 4133)* from Vilnius city centre is located about $14 \mathrm{~km}$ south-east direction and south of national significance area road No. 106 (Naujoji Vilnia-Rudamina-Paneriai) and highway A3 (VilniusMinskas) crossing. Skaidiškès is the second largest Lithuanian village in Nemėžis eldership. Is a printing house of daily newspaper „Lietuvos rytas“

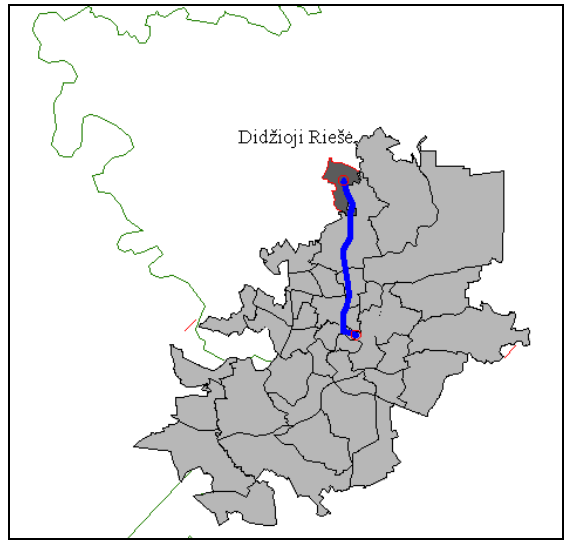

(b)

The village (population 2520)* from Vilnius city centre is located about $14 \mathrm{~km}$ south direction and is located near national significance highway A14 (Vilnius-Moletai). Former Soviet farm's central settlement. Riešè eldership and parish centre

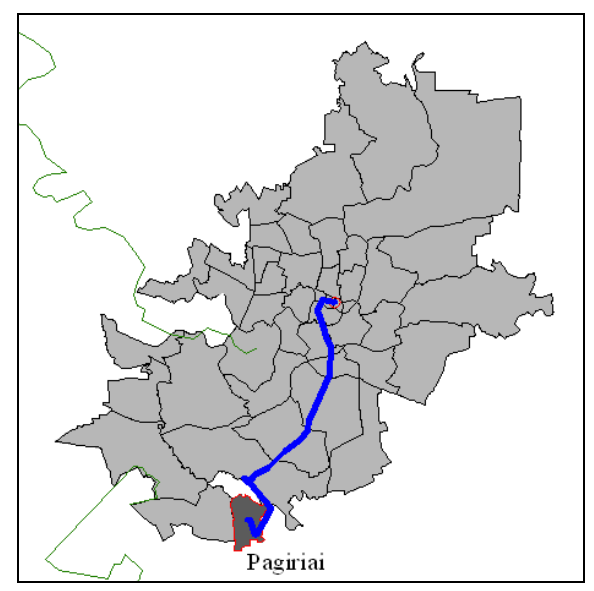

(d)

The village (population 3451)* from Vilnius city centre is located just to the south-west about $18 \mathrm{~km}$ and is located next to the road of national significance No. 202 (Kirtimai-Pagiriai-Baltoji Voke). Village is located $2 \mathrm{~km}$ away from Vilnius city Southern bypass. The western part of the village is connected to Vilnius. Pagiriai eldership's centre. This is a greenhouse factory workers settlement

Fig. 2. (a) Avižieniai, (b) Didžioji Riešè, (c) Skaidiškès and (d) Pagiriai settlements falling to Vilnius city peripheral zone

The Authors of the article have selected to analyse these four rural residential areas assigned to peripheral part of the city of Vilnius, in terms of their development priorities set in the spatial planning documents. These areas are expected to reveal a model of existing peripheral settlements development contribution to the integrity of the city structure. Assessing the quality of suburban areas development, authors relied on the results of physical and functional quality assessment of living environment.

\subsection{Development priorities of Vilnius suburban areas}

According to scientists of urbanistics, increased influence of private and commercial interests for development processes of cities and its adjacent areas has imbalanced efficiency of spatial planning works proceeded by the state and municipalities and have made external development processes partly or fully uncontrollable. Most experts say, that this situation might be 
remedied: existing spatial planning system provides additional tools for coordination of suburban areas development or there is established preparation of integrated and several municipalities involving planning documents [6] trend is reflected in master plans of Vilnius city and Vilnius district areas, outlining different development options for suburban areas.

Similar sustainable development of Vilnius city suburban residential areas network is planned in Vilnius district area master plan [9-10]:

- Form and establish hierarchical polycentric network of residential areas in a district municipality area, ensuring the most favourable social, economical and ecological conditions of the development and assumptions for a high quality of human life;

- Pursue a rational and sustainable interaction between the networks of district municipality residential areas and Vilnius city centres;

- To create conditions for the exploitation of Vilnius city agglomerating effect for the development of municipality and avoidance of the negative consequences of this effect;

- Expand high value-added businesses in the residential areas network of district municipality interacting with Vilnius city high-technology centres;

- Create preconditions for interaction between the network of district municipality residential areas and the urban system of neighbouring districts municipalities.

Nevertheless, although the city of Vilnius highly expanded territorially, it seems that the general plan developed its territory coincides with the administrative boundaries. However, the current situation shows that regardless of prevailing administrative city limits, a clear core of agglomeration is being formed with relatively evenly spaced suburban centres. Concerns arise only in further sustainable development of these centres.

Attention is drawn to the fact, that municipality of Vilnius district stands out from its region context by disproportionately enlarged settlements in the nearest suburb. The closer Vilnius city limits, the greater becomes altered traditional rural settlements of Vilnius city agglomeration effects. This reflects sintering processes in the district municipality residential network areas. Abnormal average size of the rural residential areas network (including seasonal residents) stand out these elderships: Avižieniai, Juodiškiai, Kalveliai, Marijampolis, Mickunai, Neméžis, Pagiriai, Rudamina, Sudervė, Satrininkai and Zujūnai eldership. Evolutionary trend of these elderships shows, that the agglomeration processes have started in rural residential areas network, it is continue and will continue even more, increasing diversity of the network of municipalities elderships residential areas. In addition, Vilnius district municipality is the leading one in the country in the number of settlements and the rural population in rural areas (data from the master plan, 1138 villages and 1 city). This shows that a large proportion of rural population is engaged in non-agriculture, in one way or another are related to labour relations with Vilnius city jobs. Therefore it can be said that the population will continue to grow with the development of non-agricultural businesses in rural areas, as well as with the EU structural funds assistance.

Study of the data of Vilnius district master plan shows, that $4^{\text {th }}$ level or the prospective settlements of municipalities elderships centres, such as Avižieniai, Didžioji Riešè, Juodšikiai, Nemenčinè, Nemėžis, Pagiriai, Rudamina, Zujūnai, experiencing and will experience a sintering impact of Vilnius city during perspective period, resulting in an accelerating development and will merge into agglomeration zones with expanding neighbouring rural settlements, where agric lands will remain minimal. These areas will require additional maintenance items.

Given the fact that the agglomerated rural residential areas will develop in accordance with development regularities of urban type (built-up) areas, together with social and technical infrastructure common to all the villages, falling into these zones, based on Vilnius district master plan it is firstly planned to plan U type zones in the scale level of the cities, towns master plans, preserving the old rural settlements spatial structure.

Detail analysis of individual settlements, shows that the main centres of district municipalities' elderships - Avižieniai, Didžioji Riešè, Pagiriai - will remain the multifunctional nodes of district municipality urban framework, see Table 1.

Table 1. Forecasted growth processes indicators of Avižieniai, Riešè, Pagiriai and Nemèžis elderships

\begin{tabular}{|c|c|c|c|c|c|c|c|c|c|}
\hline 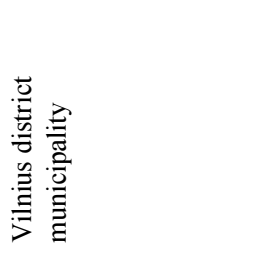 & 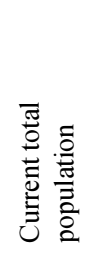 & 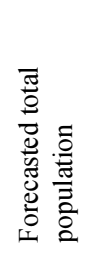 & 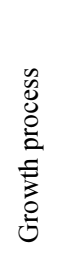 & 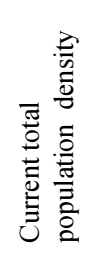 & 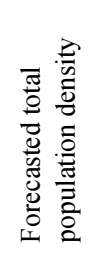 & 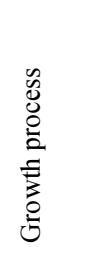 & 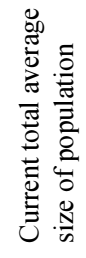 & 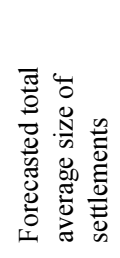 & 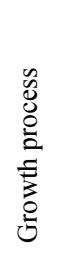 \\
\hline Avižieniai municipality & 4388 & 7450 & $170 \%$ & 84 & 143,3 & $171 \%$ & 146 & 248 & $170 \%$ \\
\hline Rieše municipality & 6580 & 8200 & $125 \%$ & 60 & 74,3 & $124 \%$ & 84 & 105 & $125 \%$ \\
\hline Pagiriai municipality & 8720 & 8700 & $100 \%$ & 98 & 97,3 & $99 \%$ & 301 & 300 & $100 \%$ \\
\hline Nemėžis municipality & 9505 & 10050 & $106 \%$ & 244 & 257,6 & $106 \%$ & 413 & 437 & $106 \%$ \\
\hline
\end{tabular}

Source: Vilnius district master plan. 


\subsection{Intensifying processes in the suburban areas}

Recent year's situation has shown that changes of the country's economy and the way of life of the population have changed the main direction of migration „from rural to urban areas“: urban population emigration to abroad countries has increased, and some residents began to move to suburbs and villages. The so called „flexible“ way of life is spreading, when people deliberately decompose their living place to a few homes, and, depending on the circumstances, living in one and then in the other, so there is a growing number of citizens with the second home. This is confirmed by the last National Census (2001 and 2011 years): although the overall assessment of the country's urban and rural population 15 percent less population is observed in both residential areas. But at the same time period assessing Vilnius city and district rural population, 9 percent of the population increase is observed in district and 56 percent increase in the villages belonging to the city municipality. Meanwhile, the city of Vilnius has lost 3 percent of the population.

Intensified tendency to migrate from the big cities to move to the suburbs primarily associated with the desire to live in more ecological environment and breathe the cleaner air. In general, ambient air quality is most objectively valued by wealthier, better educated and younger people and they are more sensitive to the negative factors: noise, air pollution, dirt, crush, intense traffic [10].

Consequences of such process are incoherent and unstructured semi-detached houses dispersion construction. Becoming attractive for living suburban and collective gardens areas without well developed social infrastructure, tend to have installed on house or its groups water and wastewater networks and heating. Public spaces are not available, except for the low technical condition streets. Therefore, the citizens remain dependent on urban social, labour and services infrastructure after switching urban environment to their preferred quality, individual and the more natural (rural) living place [11]. As for the locals, it can be stated that more active citizen's attention has an impact on local social life: besides changes in social relations, labour market and living environment is also changing. Therefore, way of life of the local rural population is changing, increasingly becoming closer to the new way of life of the population.

The authors of the article distinguish the following causes of the intensifying processes in peripheral Vilnius city areas selected for analysis:

- Due to affordable land and real estate prices in Vilnius district, conditions are allowing to move plots of land. This directly influenced Vilnius city residents to buy land plots in the areas near the city surroundings;

- According to Vilnius district elderships data, the site has a sufficiently large non-agricultural employment of the population;

- Rapid information and communications development affects job reorganization. Already a number of businesses and other organisations use permanent job model, allowing their employees to work at home or in other place convenient for them;

- Analysed settlements located 10-20 km from the city of Vilnius. This is a convenient distance to safely and quickly reach the city by car or public transport within a small period of time, where the main basic service and service companies are located;

- Analysed villages are located near state roads network, which has direct connection with the city of Vilnius. State roads and adequate transport infrastructure (hard cover, traffic control measures, a two-level crossings and the like)provides a safe and convenient local transport integration into urban streams. Given the fact that the city of Vilnius, as the capital of the country, has and will have the highest investment in transport infrastructure development, it is likely, that careful attention will constantly be paid to technical condition of the roads network in the city suburban areas;

- State roads having connection with European highways, encourages new investment in the purchase of land and creation of new transportation, storage and services companies in the settlements located near roads;

- Analysed settlements have sufficiently developed social infrastructure: there are based pre-school educational institutions, primary health care centres, administrational institutions of elderships (except Skaidiškès), religious institutions (except Skaidiškès), and trade and commercial services companies;

- It is planned to build or it is already build the centralised water, domestic sewage removal, pipeline networks, electrical networks, heat networks, installed in central parts of the settlements, in the analysed settlements over the last decade;

- Analysed settlements are located in the picturesque areas of the district, which are surrounded by isolated greenery or arrays of forests, located next to the natural and cultural objects for recreation and tourism (such as Avižieniai mound, Rudamina manor in Skaidiškès, Vanagine forest near Didžioji Riešè).

From systematic point of view, it is clear, that the urban infrastructure already in place is left to vegetate, and there is not enough density of the population in suburban areas, to pay the infrastructure [5]. In addition, monitoring stations of the environmental protection agency shows, that the highest air pollution is in places, where there is dense networks of streets and a large volume of traffic. Most air pollution is on major roads (where villages tend to expand in peripheries due to the convenient transport) as well as individual home districts, if population uses solid fuel for heating. The latter pollution depends on the season, but the pollution of transport remains relevant at all times of the year. Whether suburbs, which are more and more becoming like city, will indeed be able to continue to ensure ecological living conditions and clean air. Young people hesitating to decide where to live: in the away, but clean suburb, or in comfortable, but polluted city. Therefore, the main problem and objective remains control of urban development processes: to structure areas according to continuous construction principle, to create social infrastructure networks, diversify the types of construction, to harmonize relations of urban expansion and rural areas development [10]. 
As intensifying processes in peripheral city areas result in self-development effects, and self-development results in residents and public interests, the authors of the article highlights the need of reasonable quality assessment of the development of suburban areas, taking into account subjective evaluation of living environment by urban population, making the maximum contribution to the development of these areas.

\section{Research method}

\subsection{Description of the appropriate method}

After analyzing the data of the current suburban areas situation of the cities in Lithuania, and fundamental problems of development, assessing essential differences of urban and rural areas, the objective has been set to develop theoretical model for assessing the quality of suburban areas development. As mentioned in the previous sections, the researches on the living environment quality are not a new thing, and are described using both, quantitative and qualitative indicators. The analysis of scientific literature shows that such studies are difficult to adapt in practice due to diversity of assessed indicators. According to the urban researchers, the system of indicators of the urban living environment has to determine the current physical condition of the city, the ongoing processes, and the strengths of urban progress and also reflect the current economic, ecological and social condition of the city [12]. There are social, economic and agriculture factors assessing the advantage of attractive rural residential areas [13].

In view of the above provisions, residential environmental indicators provided in the previous section have been systematized. There are three sets of social groups that have a direct connection with the expansion of suburban areas: local residents living and working in the suburbs; expats living in the suburbs, but working in the city, and citizens who live and work in the city or have a second home in the suburbs. The approach of the three social groups to the Vilnius city suburban areas will perform comparative analysis of the mentioned Vilnius district settlements, in order to assess the adequacy of the formed suburban areas indicators system to the formation of theoretical model. The following are the primary steps for the formation of the model, see Figure 3.

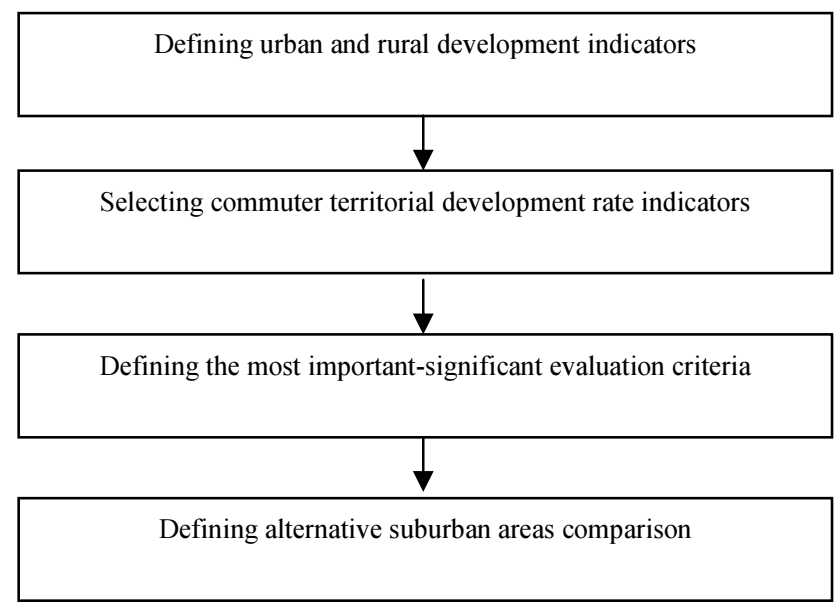

Fig. 3. Scheme of theoretical model

The authors conducted analytical research within the analysed Vilnius city suburban areas in period of 2013 and 2014. Study objective - to create a quality assessment model of development of the suburban areas, based on the principles of sustainable development, enabling a comprehensive analysis of the objective and subjective factors pertaining quality of the living environment.

Significance or relevance of the indicators shows the indicator's degree of influence on the final result. Sufficiently precise significance of indicators can be determined by expert interviews and statistical methods. Regardless of the assessment of the applied method, the logic is the same: the prime rate will be the highest weight. The simplest one of the applied methods is the ranking of indicators. For this purpose, the actual values of the analysed indicators should be compared with the reference values. Then it results in the adjusted values of indicators, which are scored. For scoring assessment the indirect method of determining the weights of the indicators is used, when the expert assesses the weight of each indicator, not linking one estimate to the other estimates of the indicators. Based on such indicators estimates assessment methodology, the reference indicators values and the ranking scale has been set. Reference indexes are obtained under separate indicators calculation methods (economic, regulatory, and so on) and statistical research data. 


\section{Research method application}

In order to efficiently select significant indicators estimating suburban areas, expert evaluation has been performed. Expert survey method has been applied. In this case, interview has been performed with 10 experts, operating in spatial planning, design and building of urban systems, project assessment fields and working in both, public institutions and private companies, for the purpose of finding out which indicators assessing development of suburban areas are most significant and can be applied in practice. The questionnaire contained questions describing the general, social, economic, engineering infrastructure, natural environment indicators. Several possible options are available for the answers, describing the qualitative influence of the questions for individual social groups. In order to structure the expert answers and make appropriate conclusions, a point system has been used for evaluation of questions: 4 - excellent, 3 - good, 2 - fair, 1 satisfactory 0 - badly. The first position with higher points sum has been devolved for Skaidiškès, see Table 3.

Table 4. The objective expert scoring

\begin{tabular}{l|l|l|l|l|l}
\hline Indicators & Measuring unit. & Avižieniai & Didžioji Riešè & Skaidiškès & Pagiriai \\
\hline Land price & Points & 1,00 & 2,00 & 4,00 & 3,00 \\
\hline Housing price & Points & 2,00 & 2,00 & 4,00 & 3,00 \\
\hline Housing supply of engineering networks & Points & 1,00 & 4,00 & 3,00 & 2,00 \\
\hline Transport infrastructure & Points & 4,00 & 3,00 & 4,00 & 3,00 \\
\hline Number of enterprises/institutions & Points & 3,00 & 4,00 & 2,00 & 1,00 \\
\hline Population density & Points & 4,00 & 1,00 & 2,00 & 3,00 \\
\hline Commuting time & Points & 4,00 & 2,00 & 3,00 & 1,00 \\
\hline Distance of the canter & Points & 4,00 & 3,00 & 2,00 & 1,00 \\
\hline Density of green areas per inhabitant & Points & 3,00 & 1,00 & 2,00 & 4,00 \\
\hline Investments for settlement & Points & 1,00 & 2,00 & 4,00 & 3,00 \\
\hline Land price & Points & 1,00 & 2,00 & 4,00 & 3,00 \\
\hline SUM & & 27 & 24 & 30 & 24 \\
\hline
\end{tabular}

The same point value can be assigned to the certain social groups as subjective factor. Four variants have been selected for calculations: Avižieniai (Variant No1), Didžioji Riešè (Variant No2), Skaidiškès (Variant No3), Pagiriai (Variant No4).

The following calculation presents the assessment of the significance of the living area indicators proposed by one social group, it is emigrated citizens living in suburban area, but working in the city and structured results of expert evaluation.

Table 4. The initial decision-making matrix

\begin{tabular}{|c|c|c|c|c|c|c|c|}
\hline \multirow[t]{2}{*}{ Indicators } & \multirow[t]{2}{*}{ Measuring unit. } & \multirow[t]{2}{*}{ Directions of optimization } & \multirow[t]{2}{*}{ Weight } & \multicolumn{4}{|c|}{ Variants } \\
\hline & & & & Var1 & Var2 & Var3 & Var4 \\
\hline Land price & Points & $\max$ & 0,08 & 1,00 & 2,00 & 4,00 & 3,00 \\
\hline Housing price & Points & $\max$ & 0,07 & 2,00 & 2,00 & 4,00 & 3,00 \\
\hline Housing supply of engineering networks & Points & $\max$ & 0,10 & 1,00 & 4,00 & 3,00 & 2,00 \\
\hline Transport infrastructure & Points & $\max$ & 0,07 & 4,00 & 3,00 & 4,00 & 3,00 \\
\hline Number of enterprises/institutions & Points & $\max$ & 0,14 & 3,00 & 4,00 & 2,00 & 1,00 \\
\hline Population density & Points & $\max$ & 0,15 & 4,00 & 1,00 & 2,00 & 3,00 \\
\hline Commuting time & Points & $\max$ & 0,09 & 4,00 & 2,00 & 3,00 & 1,00 \\
\hline Distance of the canter & Points & $\max$ & 0,11 & 4,00 & 3,00 & 2,00 & 1,00 \\
\hline Density of green areas per inhabitant & Points & $\max$ & 0,08 & 3,00 & 1,00 & 2,00 & 4,00 \\
\hline Investments for settlement & Points & $\max$ & 0,10 & 1,00 & 2,00 & 4,00 & 3,00 \\
\hline Land price & Points & $\max$ & 0,08 & 1,00 & 2,00 & 4,00 & 3,00 \\
\hline
\end{tabular}

Expert system was used to evaluate actual weights of indicators presented in Table 4. Eight experts were selected from inhabitants to participate in this study. Initial data and calculation results were presented in Table 5. 
Table 5. The initial data and determination of indicators weights using expert method

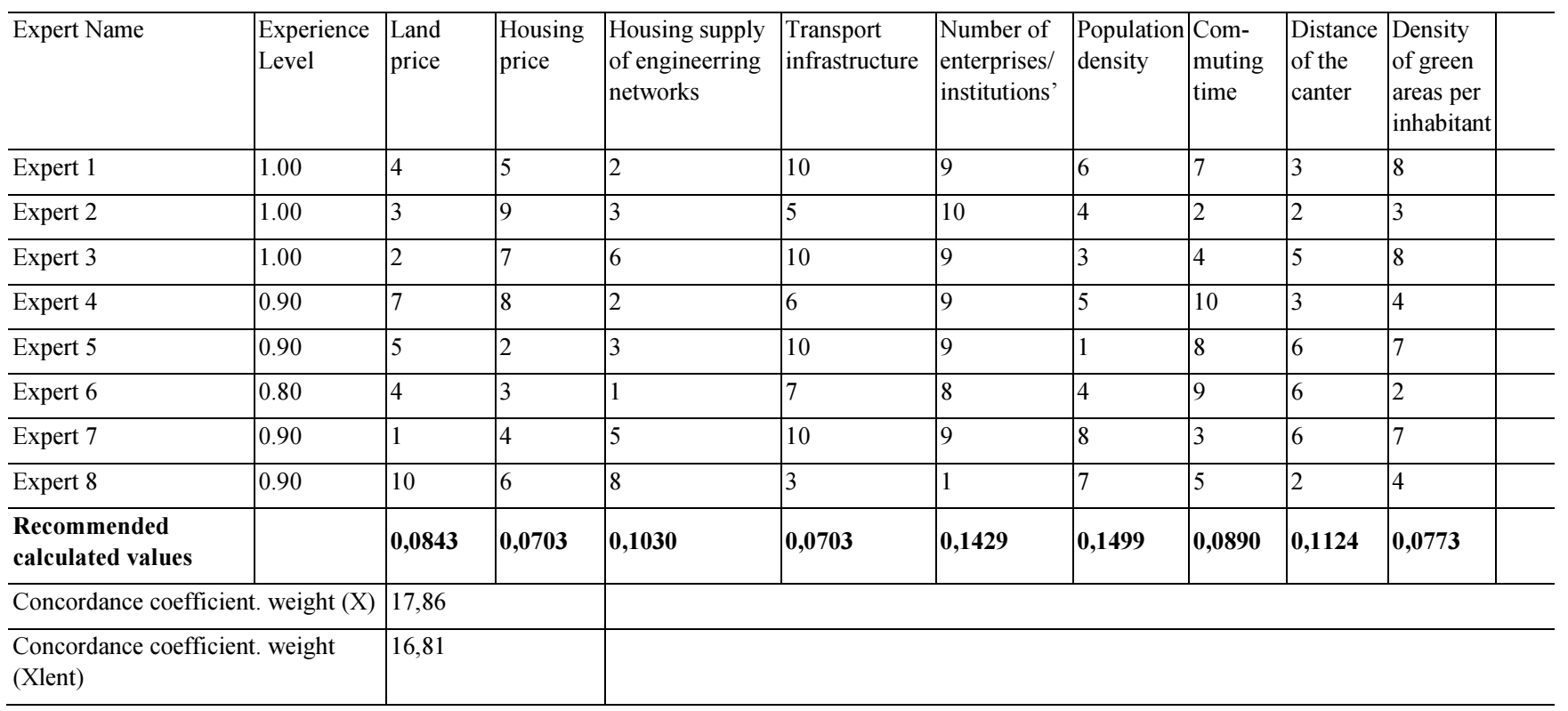

The assessment of the measures was performed with the application with the TOPSIS_A method. TOPSIS_A method can be used, when the number of the available alternatives is small and problem solution requires that absolute significance values of the alternatives should be determined. In making the calculations according to this method, absolute, rather than relative, significance of the alternatives describing presented variants is determined [14]. In the following table are presented intermediate calculations - normalization of indicators initial data.

All needed calculations and listing of priorities were made using IT system software DSS_MS [14]. Two top priority selection places obtained in the process of evaluation which can be recommended are given in Table 6 .

Table 6. Determination of the rational places variants, using TOPSIS_A method.

\begin{tabular}{l|l|l|l}
\hline Variant priority & Variant № & $\mathrm{K}_{\text {Bit value }}$ & Variant \\
\hline 1 & 1 & 1.0000 & Avižieniai \\
\hline 2 & 3 & 0.8868 & Skaidiškès \\
\hline
\end{tabular}

Based on the analysis of the 4 chosen variants and calculations, using TOPSIS_A method, the most perspective settlement considering to subjective opinion calculations is Avižieniai.

\section{Research results}

The research results show that underlying development of settlements in city peripheral areas due to territorial planning documents are in line with the perspective arrangements provided by the subjective opinion assessment of selected experts' from particular social group. Avižieniai has been identified as the most attractive settlement between four key settlements in Vilnius peripheral zone for potential city emigrants.

The territorial planners are liable to accept this fact and with noting the maximum population growth in Avižieniai neighborhood are providing the need to develop this settlement in a greater priority than others. Meanwhile the experts' assessment of objective indicators shows that the most sustainable development in relation to the Vilnius city and its peripheral zone is Skaidiškès settlement.

Comparing the results of objective indicators of living environment provided by experts and subjective indicators provided by potential peripheral immigrants we can see that their opinion differs. Therefore, the authors conclude that the social group needs which has greatest influence on the formation of the peripheral areas have been evaluated by planners in quantitatively way taking into consideration only the increase of particular social group in the territory.

Hereby, it is reinforced unsubstantiated practical implementation of sustainable development in territorial planning documents with censure to stop the increase of sustainability in more corresponding and developed territories (e. g. Skaidiškès). This research proposes the method which is suitable for evidence finding to substantiate the integration links between further urban and rural territorial development in decision making and selecting the best alternative.

The interim results showed that alternative choice of separate settlements is determined by subjective factors. For the qualitative planning of peripheral territorial development in further research it is important to evaluate other social groups' needs for the living environment. 


\section{References}

[1] Schneider, A.; Woodcock, C. E. 2008. Compact, Dispersed, Fragmented, Extensive? A Comparison of Urban Growth in Twenty-five Global Cities using Remotely Sensed Data, Pattern Metrics and Census Information, Urban Stud 45(3): 659-692. http://dx.doi.org/10.1177/0042098007087340

[2] Jauhiainen, J. 2006. Demographic, employment and administrative challenges for urban policies in Estonia. European Planning Studies 14(2): 273283. http://dx.doi.org/10.1080/09654310500418291

[3] Couch, C.; Karecha, J.; Nuissl, H.; Rink, D. 2005. Decline and Sprawl: An evolving type of urban development - observed in Liverpool and Leipzig, European Planning Studies 1(13): 117-136. http://dx.doi.org/10.1080/0965431042000312433

[4] Future Orientations for Cities. ESPON 2013 Programme, Applied Research. Final Report: 2013. 25 p.

[5] Bardauskienè, D.; Pakalnis, M. Current Trends and Management of Urban Development in Lithuania, in Proceedings REAL CORP 2011, 18-20 May 2011, Essen. http://www.corp.at. ISBN: 978-3-9503110-0-6 (CD-ROM); ISBN: 978-3-9503110-1-3.

[6] Cirtautas, M. 2010. Modern suburban area concept, Science - Future of Lithuania. K.Šešèlgis readings 2(3): 11-1. Vilnius: Technika. Available from Internet: www.mla.vgtu.lt

[7] Juškevičius, P.; Burinskienė, M.; Paliulis, G. M.; Gaučè, K. 2013. Urbanistika: procesai, problemos, planavimas, pletra. Vilnius: Technika. 266 p. ISBN 978-609-457-429-0. http://dx.doi.org/10.3846/1447-S

[8] Juškevicius, P.; Valeika, V. 2007. Lietuvos miestu sistemu raida. Vilnius: Baltijos kopija. 111 p. ISBN 978-9955-568-58-2.

[9] Vilnius city general plan until 2015 year. 2006. Confirmed by Vilnius city municipal council 2006 year, December.

[10] Vilnius district municipality area general plan. 2008. Confirmed Vilnius district Municipality council 2009 year.

[11] Rudzkienè, V.; Burinskienė, M. 2007. Plètros krypčiu vertinimo ir valdymo informaciniai modeliai. Vilnius: Technika. ISBN 978-9955-28-217-4, 3435. http://dx.doi.org/10.3846/1397-M

[12] Burinskienè, M.; Rudzkienè, V.; Venckauskaite, J. 2011. Effects of quality of life on the price of real estate in Vilnius city, International journal of strategic property management 15(3): 295-311.

[13] Vidickienè, D.; Melnikienè, R. 2008. Paramos teikimo Lietuvos kaimo regionams kriteriju vertinimas. Vadybos mokslas ir studijos - kaimo verslų ir jų infrastruktūros plètrai. 1(12): 176-182.

[14] Šarka, V.; Zavadskas, E. K.; Ustinovičius, L.; Šarkienè, E.; Ignatavičius, Č. 2008. System of project multicriteria decision synthesis in construction. Technological and economic development of economy, Baltic Journal on Sustainbility 14(4): 546-565. Vilnius: Technika. ISSN $1392-8619$. 